\title{
Management of type 2 diabetes mellitus in the elderly: role of the pharmacist in a multidisciplinary health care team
}

This article was published in the following Dove Press journal:

Journal of Multidisciplinary Healthcare

24 May 2011

Number of times this article has been viewed

\author{
Samuel Grossman \\ Department of Veterans Affairs, \\ New York Harbor Healthcare System, \\ New York, NY, USA; Diabetes Care \\ On-The-Go Inc, Brooklyn, NY, USA; \\ Hunter-Bellevue School of Nursing, \\ Hunter College, City University \\ of New York, New York, NY, USA; \\ Arnold and Marie Schwartz College \\ of Pharmacy of Long Island University, \\ Brooklyn, NY, USA; Garden State \\ Association of Diabetes Educators, \\ Edison, NJ, USA
}

\begin{abstract}
Intensive glycemic control using insulin therapy may be appropriate for many healthy older adults to reduce premature mortality and morbidity, improve quality of life, and reduce health care costs. However, frail elderly people are more prone to develop complications from hypoglycemia, such as confusion and dementia. Overall, older persons with type 2 diabetes mellitus are at greater risk of death from cardiovascular disease (CVD) than from intermittent hyperglycemia; therefore, diabetes management should always include CVD prevention and treatment in this patient population. Pharmacists can provide a comprehensive medication review with subsequent recommendations to individualize therapy based on medical and cognitive status. As part of the patient's health care team, pharmacists can provide continuity of care and communication with other members of the patient's health care team. In addition, pharmacists can act as educators and patient advocates and establish patient-specific goals to increase medication effectiveness, adherence to a medication regimen, and minimize the likelihood of adverse events.
\end{abstract}

Keywords: glycemic control, hyperglycemia, continuity of care, hypertension and cardiovascular disease, elderly, type 2 diabetes, pharmacist

\section{Introduction}

More than $20 \%$ of elderly Americans ( 65 years or older) have type 2 diabetes mellitus (T2DM). ${ }^{1}$ T2DM is associated with increased morbidity and mortality in the elderly, ${ }^{2}$ and half of elderly patients receiving diabetes treatment do not achieve adequate glycemic control. ${ }^{3}$ Although glycemic control is important, elderly patients with diabetes are more likely to benefit from the additional treatment for hypertension and cardiovascular disease (CVD) than with only tight glycemic control. ${ }^{1}$ Compared with a younger cohort, older Americans with diabetes are more likely to have geriatric syndrome, which is a cluster of conditions that include injurious falls, cognitive impairment, and depression. ${ }^{4}$ These conditions can complicate the management of diabetes and increase the likelihood of hypoglycemia, confusion, and dementia. As part of the patient's health care team, pharmacists can act as educators and patient advocates and establish patient-specific goals to increase medication effectiveness and adherence to their medication regimen, and minimize adverse events. For example, pharmacists who participated in the Diabetes Ten City Challenge (DTCC) provided coaching, used evidence-based diabetes care guidelines, and implemented patient self-management strategies, which resulted in reductions in glycosylated hemoglobin, low-density lipoprotein cholesterol, and systolic blood pressure in 573 patients with diabetes after 1 year of follow-up. ${ }^{5}$ Pharmacists referred patients to physicians for further assessment,
Correspondence: Samuel Grossman 20 Dale Drive, Edison, NJ 08820, USA

Tel +l 9173857403

Fax +I 2129733374

Email samnlisa@optonline.net 
contacted other providers (such as a dietitian) for intensive nutrition education, or communicated with diabetes education centers for additional education support.

\section{Special considerations for elderly patients with diabetes}

Elderly persons are more likely to develop and be more susceptible to diabetes-related complications. ${ }^{1}$ In particular, this population should be evaluated for complications that develop over short periods of time and/or for those that would significantly impair functional status, such as vision and lower-extremity complications (ie, peripheral neuropathy and subsequent diabetic foot infections). Diabetes treatment-related complications may be more problematic in elderly persons than in the nonelderly; for example, hypoglycemia may aggravate dementia ${ }^{6}$ and can increase the risk of falls. Elderly persons may be at greater risk than younger patients for comorbid conditions such as depression, which can lead to treatment apathy and reduced medication effectiveness.

Adherence to a prescribed medication regimen should not be assumed. About 30\% of Medicare patients with medication coverage are nonadherent to their medication regimens for financial reasons. ${ }^{7}$ Patients who repeatedly miss medical appointments may be at increased risk for nonadherence and will likely require diligent follow-up measures to resolve underlying issues. A comprehensive medication review by the pharmacist, which includes medication adherence and individual strategies to decrease nonadherence, can help identify other medication-related issues. Elderly patients may not be able to read their medication instructions or understand how to take the medications; these issues can be addressed with additional education and repeated interventions. Taking multiple drugs several times a day can lead to medication errors, adverse events, reduced medication efficacy, increased costs, and poor regimen adherence. ${ }^{8}$ Polypharmacy is common, as elderly persons tend to keep medications that were prescribed years ago, and may keep medications that were switched to another drug within the same drug class after a hospitalization. Medication reconciliation should include discontinuing medications that are a therapeutic duplication, or that contain the same active ingredient but were prescribed as a different formulation or as part of a combination drug.

Diabetes self-management weaknesses and the patient's history of hypoglycemic events should be addressed by a pharmacist and other health care providers so action can be taken to prevent future events. Assessing for cognitive decline or depression is necessary to differentiate these disorders from symptoms related to hypoglycemia. If a patient is diagnosed with and treated for depression, the patient should be reevaluated to assess treatment efficacy and symptom improvement. Working with the patient and prescribers to simplify treatment regimens may increase medication regimen adherence, minimize adverse effects, and increase medication effectiveness.

\section{Diabetes treatment guidelines for the elderly}

Treatment goals should be developed and achieved in line with the elderly patient's medical, functional, social, and financial status. ${ }^{4}$ Aggressive treatment is appropriate for most healthy older adults to reduce premature mortality and morbidity, improve quality of life, and reduce health care costs. ${ }^{1}$ These patients may benefit from regimens that include insulin to allow dosage adjustment with food intake and level of exercise. However, due to a patient's advancing age, treatment decisions become more complex, and their capacity to cope with adverse effects and complicated treatment regimens declines. To minimize the risk of hypoglycemia and associated complications such as falls or confusion, less aggressive fasting glucose targets may be necessary for frail elderly patients ${ }^{9}$ (those with an unintentional weight loss of 10 pounds in the past year, chronic exhaustion, and low grip strength, walking speed, and physical activity). ${ }^{10}$ For these frail elderly patients, treatment selection should include therapies with a low risk of hypoglycemia, such as metformin or an incretin mimetic; therapies with a high risk of hypoglycemia, such as long-acting sulfonylureas (ie, chlorpropamide or glyburide), should be avoided.

The long-term benefits of tight control of fasting blood glucose will likely not be observed in patients with advanced age. Cardiovascular disease is a leading cause of death in this population, ${ }^{11}$ and a greater reduction in morbidity and mortality is expected by controlling CVD risk factors. ${ }^{12}$ Elevated postprandial glucose (PPG) levels may increase the risk of CVD. ${ }^{13}$ Data on PPG control in the elderly are limited; however, selecting drug therapy that targets PPG should be considered to further reduce CVD risk. Elderly patients and caregivers should be educated about controlling CVD risk factors by discussing the importance of smoking cessation and blood pressure control. Pharmacists can provide continuity of care by communicating changes in over-the-counter 
medications or herbal therapies to the patient's prescriber and other health care team members.

\section{Treatment options for diabetes in the elderly}

Dietary changes may only moderately help with glycemic control in the elderly. These patients may have defective dentition, loss of taste/poor appetite, or an unwillingness to change a lifetime of eating habits. ${ }^{9}$ Elderly patients should consult with a dietitian to create a well balanced diet that facilitates weight loss (if needed) and helps maintain glycemic control. ${ }^{14}$ Exercise should be consistent and based on what the patient can tolerate. Preferably, these patients should walk or swim for 30 minutes a day to maintain muscle conditioning. ${ }^{9}$ Foot and eye care should be discussed with the patient. Pharmacists should review nonpharmacologic therapy, including lifestyle modifications, to determine if any changes could be made to improve effectiveness of recommended nonpharmacologic interventions. In addition, the pharmacist could discuss daily foot care, and could conduct a basic foot exam to assess pedal pulses, abnormalities in anatomy, and changes in sensation.

Pharmacologic treatment options are briefly presented in Table 1., ${ }^{1,4,9,14-19}$ To assess the effectiveness and safety of antihyperglycemic medications, the pharmacist should

Table I Summary points for drugs used to treat diabetes in the elderly

\begin{tabular}{|c|c|c|c|}
\hline Drug class/name & $\begin{array}{l}\text { Possible drug or disease } \\
\text { interactions }\end{array}$ & $\begin{array}{l}\text { Adverse events that } \\
\text { may limit use }\end{array}$ & Important notes \\
\hline $\begin{array}{l}\text { Alpha-glucosidase } \\
\text { inhibitors }{ }^{9}\end{array}$ & $\begin{array}{l}\text { Erratic oral intake; must } \\
\text { take with main meals to be } \\
\text { effective }\end{array}$ & Gastrointestinal effects & Adjust dose with renal or liver dysfunction \\
\hline $\begin{array}{l}\text { Meglitinides } \\
\text { Incretin therapies } \\
\text { DPP-4 inhibitors }{ }^{15}\end{array}$ & $\begin{array}{l}\text { Frequent daily dosing } \\
\text { Concomitant use with } \\
\text { insulin secretagogues } \\
\text { increases risk of } \\
\text { hypoglycemia }\end{array}$ & $\begin{array}{l}\text { Hypoglycemia, weight gain } \\
\text { Headache, infection, } \\
\text { dermatologic effects }{ }^{16}\end{array}$ & $\begin{array}{l}\text { Rapid onset } \\
\text { - Effects are glucose dependent, so low risk } \\
\text { for hypoglycemia } \\
\text { - Weight neutral } \\
\text { - Target PPG levels }\end{array}$ \\
\hline $\begin{array}{l}\text { Incretin therapies } \\
\text { GLP-I agonists }{ }^{15}\end{array}$ & $\begin{array}{l}\text { Concomitant use with } \\
\text { insulin secretagogues } \\
\text { increases risk of } \\
\text { hypoglycemia }\end{array}$ & $\begin{array}{l}\text { Gastrointestinal effects (less than } \\
\text { alpha-glucosidase inhibitors), }{ }^{15} \\
\text { pancreatitis, immune reactions } \\
\text { (incidence less with liraglutide } \\
\text { than exenatide) }{ }^{16}\end{array}$ & $\begin{array}{l}\text { - Effects are glucose dependent, so low risk } \\
\text { for hypoglycemia } \\
\text { - Weight loss } \\
\text { - Target PPG levels } \\
\text { - Decrease blood pressure; improve other } \\
\text { CVD markers }{ }^{16}\end{array}$ \\
\hline Insulins ${ }^{17,18}$ & $\begin{array}{l}\text { Erratic oral intake } \\
\text { can increase risk of } \\
\text { hypoglycemia; low vision } \\
\text { and dexterity may limit use } \\
\text { of vial and syringes, clinician } \\
\text { inertia }\end{array}$ & Hypoglycemia & $\begin{array}{l}\text { - Better glycemic control if difficulty adhering } \\
\text { to oral medications, receiving multiple oral } \\
\text { medications, or not achieving glycemic targets } \\
\text { than with oral medications alone } \\
\text { - Early use may restore and improve beta-cell } \\
\text { function } \\
\text { - Insulin pens increase adherence for patients } \\
\text { with low vision and/or dexterity issues }\end{array}$ \\
\hline Metformin' & Impaired renal function & $\begin{array}{l}\text { Lactic acidosis (rare but serious), } \\
\text { gastrointestinal effects }\end{array}$ & $\begin{array}{l}\text { - Measure serum creatinine and liver function } \\
\text { periodically and with any increase in dose } \\
\text { - Weight neutral versus placebo } \\
\text { - Avoid initiating in patients } \geq 80 \text { years of age } \\
\text { unless creatinine clearance is within normal } \\
\text { limits }\end{array}$ \\
\hline Pioglitazone ${ }^{14}$ & $\begin{array}{l}\text { Class III and class IV } \\
\text { congestive heart failure }\end{array}$ & $\begin{array}{l}\text { Weight gain, fluid } \\
\text { retention, peripheral edema, } \\
\text { fractures among women }{ }^{19}\end{array}$ & Hypoglycemia rare \\
\hline Sulfonylureas ${ }^{4}$ & $\begin{array}{l}\text { Erratic oral intake can } \\
\text { increase risk of hypoglycemia } \\
\text { with long-acting agents }\end{array}$ & Hypoglycemia, weight gain & $\begin{array}{l}\text { Avoid long-acting sulfonylureas; short-acting } \\
\text { (ie, glipizide) minimize risk of nocturnal } \\
\text { hypoglycemia, and may also help avoid } \\
\text { hypoglycemia in patients with erratic oral intake }\end{array}$ \\
\hline
\end{tabular}

Abbreviations: CVD, cardiovascular disease; DPP-4, dipeptidyl peptidase IV; GLP-I, glucagon-like peptide I; NPH, neutral protamine Hagedorn; PPG, postprandial glucose. 
carefully monitor glucose levels (including PPG), weight, renal function, and blood pressure. Elderly persons are more likely to have renal dysfunction than other adults. Therefore, medications such as metformin should be used with caution in these patients because of the risk of developing lactic acidosis, a rare but potentially fatal adverse effect that is more common in those with renal dysfunction. Gastrointestinal adverse effects can be debilitating in the older person. For example, glucagon-like peptide 1 (GLP-1) agonists are associated with treatment-limiting nausea; however, these agents have a low risk of hypoglycemia. The pharmacist can discuss ways to reduce or manage drug-induced nausea or recommend switching to a therapy with a low risk of this adverse effect. Clinician inertia, delaying insulin therapy because of fears of hypoglycemia, and perceived lack of benefit can also be addressed by a pharmacist by communicating patient-specific needs to other members of the health care team.

As an individual ages, beta-cell function declines. Studies suggest that early use of insulin in the elderly restores and improves beta-cell function and induces disease remission. ${ }^{18,20}$ Simple insulin regimens with premeasured doses and easier injection systems (eg, insulin pens with easy-to-set dosages) are preferred in the elderly patient. ${ }^{21}$ Timing of insulin doses relative to meals and adjusting doses based on meal content and caloric intake minimize the risk of hypoglycemia. For some elderly people, two daily injections using premixed insulin analog preparations or a long-acting insulin analog for basal control may be preferred to multiple oral medications. Fasting and post-prandial glucose levels should be monitored and assessed to determine if target levels have been obtained. If control is unsatisfactory, a dose of rapid-acting insulin analog for prandial glucose control during the main meal could be added to the basal regimen. For the healthy older person, a combination of rapid- and long-acting insulin analogs would provide tight glycemic control and allow dosing flexibility. Elderly people who are not frail are more likely to benefit from long-term tight glycemic control, which is associated with a reduced risk of diabetes-related microvascular complications and

Table 2 Pharmacist-provided patient care and associated outcomes in older patients with type 2 diabetes mellitus

\begin{tabular}{|c|c|c|}
\hline Study & Methods & Results \\
\hline Cranor et $\mathrm{a}^{24}$ & $\begin{array}{l}\text { - Quasi-experimental, longitudinal, pre and post cohort } \\
\text { trial design } \\
\text { - I } 2 \text { community-based pharmacists trained in } \\
\text { diabetes education } \\
\text { - Asheville Project } \\
\text { - Change in clinical and economic outcomes before } \\
\text { and after up to } 5 \text { years of implementation of services }\end{array}$ & $\begin{array}{l}\text { - } \mathrm{n}=620 \text { financial cohort, } \mathrm{n}=565 \text { clinical cohort } \\
\text { - Baseline median age } 48 \text { years } \\
\text { - Median AIc decreased by } 0.8 \% \text { after first follow-up } \\
\text { visit }(P<0.00 \mathrm{I}) \\
\text { - LDL-C decreased by } 2.5 \mathrm{mg} / \mathrm{dL} \text { after the first follow-up } \\
\text { visit }(P=0.13) \\
\text { - Total direct medical costs decreased by US } \$ 1662-\$ 3356 \\
\text { per patient per year depending on the follow-up year, } \\
\text { despite increases in mean prescription costs }\end{array}$ \\
\hline Fera et $\mathrm{a}^{5}$ & $\begin{array}{l}\text { - Prospective, observational, pre- and post-cohort } \\
\text { trial design } \\
\text { - Collaborative practice model } \\
\text { - Community-based pharmacists } \\
\text { - Evidence-based guidelines } \\
\text { - Clinical and economic outcomes } \\
\text { - Diabetes Ten City Challenge } \\
\text { - Change in clinical and economic outcomes before } \\
\text { and after I year of implementation of services }\end{array}$ & $\begin{array}{l}\text { - } \mathrm{N}=573 \\
\text { - } 42 \% \text { were } 60 \text { years or older } \\
\text { - Mean Alc decreased by } 0.4 \%(P=0.002) \\
\text { - Mean LDL-C decreased by } 4 \mathrm{mg} / \mathrm{dL}(P<0.00 \mathrm{I}) \\
\text { - Mean SBP decreased by } 3 \mathrm{mmHg}(P<0.00 \mathrm{I}) \\
\text { - Average total health care costs per patient per year } \\
\text { decreased by US } \$ 1079(7.2 \%) \\
\text { - Influenza vaccination rate increased by } 33 \% \\
\text { - Foot examination rate increased by } 40 \%\end{array}$ \\
\hline Jameson and Baty ${ }^{25}$ & $\begin{array}{l}\text { - Prospective, randomized, controlled trial } \\
\text { - Pharmacist management versus usual medical care } \\
\text { - Change in Alc after I year of care } \\
\text { - Poorly controlled diabetes (AIc >9\%) } \\
\text { - One pharmacist with advanced diabetes education training } \\
\text { - Intervention consisted of targeted patient outreach } \\
\text { program plus medication management, patient education, } \\
\text { disease control by a pharmacist } \\
\text { - Control group used targeted patient outreach programs } \\
\text { and registries }\end{array}$ & $\begin{array}{l}\text { - } \mathrm{N}=\mathrm{I} 03 \text { (intervention group } \mathrm{n}=52 \text {, control group } \mathrm{n}=5 \mathrm{I} \text { ) } \\
\text { - Mean age } 49 \text { years } \\
\text { - Mean AIc decreased by I.5\% for the intervention group } \\
\text { and } 0.4 \% \text { for the control group }(P=0.06) \\
\text { - Alc decreased by at least I\% for } 67.3 \% \text { versus } 41.2 \% \text {, } \\
\text { respectively }(P=0.02) \\
\text { - Male and nonwhite patients had greater improvement } \\
\text { in AIc than female or white patients }\end{array}$ \\
\hline
\end{tabular}

Abbreviations: AIc, glycosylated hemoglobin; LDL-C, low-density lipoprotein cholesterol; SBP, systolic blood pressure. 
amputations. In addition, long-acting insulin analogs do not have the pronounced peak observed with neutral protamine Hagedorn (NPH) insulin and are less likely to produce nocturnal hypoglycemia. ${ }^{22}$

Pharmacists are in a key position to improve diabetes control in this potentially high-risk population. In observational and controlled trials, medication management and diabetes education provided by the pharmacist has been reported to improve A1c, blood pressure, and lipid parameters. ${ }^{23}$ In addition, these services increase patient satisfaction and decrease health care costs. The DTCC is an example of how pharmacy practice around the country is evolving to include patient education, medication therapy management, basic physical assessment, routine patient and caregiver follow up, and constant collaboration with other health care providers. ${ }^{5}$ A brief list of recently published primary literature evaluating clinical outcomes and pharmacist-provided diabetes care of the older patient is provided in Table $2 .^{5,24,25}$

Older persons with diabetes are at greater risk of death from CVD than from intermittent hyperglycemia. Frail elderly people are more prone to develop complications from hypoglycemia, such as confusion and dementia. Continuity of care, communication with other members of the patient's health care team, and a comprehensive medication review by the pharmacist, with subsequent recommendations to individualize therapy based on medical and cognitive status, will minimize adverse effects and optimize treatment effectiveness.

\section{Acknowledgments}

The author wishes to thank Beatriz Manzor Mitrzyk, PharmD, of MedVal Scientific Information Services, LLC, for providing medical writing and editorial assistance. This manuscript was prepared according to the International Society for Medical Publication Professionals' Good Publication Practice for Communicating Company-Sponsored Medical Research: the GPP2 Guidelines. Funding to support the preparation of this manuscript was provided by Novo Nordisk Inc.

\section{Disclosure}

The author reports no conflicts of interest in this work.

\section{References}

1. American Diabetes Association. Standards of medical care in diabetes - 2011. Diabetes Care. 2011;34(Suppl 1):S11-S61.
2. Sloan FA, Bethel MA, Ruiz D Jr, Shea AH, Feinglos MN. The growing burden of diabetes mellitus in the US elderly population. Arch Intern Med. 2008;168:192-199.

3. Suh DC, Kim CM, Choi IS, Plauschinat CA. Comorbid conditions and glycemic control in elderly patients with type 2 diabetes mellitus, 1988 to 1994 to 1999 to 2004. J Am Geriatr Soc. 2008;56:484-492.

4. Joslin Diabetes Center and Joslin Clinic. Guideline for the care of the older adult with diabetes. Available from: http://www.joslin.org/docs/ Guideline_For_Care_Of_Older_Adults_with_Diabetes.pdf. Accessed March 21, 2011.

5. Fera T, Bluml BM, Ellis WM. Diabetes Ten City Challenge: final economic and clinical results. J Am Pharm Assoc (2003). 2009:49:383-391.

6. Whitmer RA, Karter AJ, Yaffe K, Quesenberry CP Jr, Selby JV. Hypoglycemic episodes and risk of dementia in older patients with type 2 diabetes mellitus. JAMA. 2009;301:1565-1572.

7. American Association of Clinical Endocrinologists. Medical guidelines for clinical practice for the management of diabetes mellitus. Endocr Pract. 2007;13(Suppl 1):4-68.

8. Boyd CM, Darer J, Boult C, Fried LP, Boult L, Wu AW. Clinical practice guidelines and quality of care for older patients with multiple comorbid diseases: implications for pay for performance. JAMA. 2005;294:716-724.

9. California Healthcare Foundation. Guidelines for improving the care of the older person with diabetes mellitus. J Am Geriatr Soc. 2003; 51(5 Suppl):S265-S280.

10. Ahmed N, Mandel R, Fain MJ. Frailty: an emerging geriatric syndrome. Am J Med. 2007;120:748-753.

11. Stratton IM, Adler AI, Neil HA, et al. Association of glycaemia with macrovascular and microvascular complications of type 2 diabetes (UKPDS 35): prospective observational study. BMJ. 2000;321:405-412.

12. Nathan DM, Buse JB, Davidson MB, et al. Medical management of hyperglycemia in type 2 diabetes: a consensus algorithm for the initiation and adjustment of therapy. A consensus statement of the American Diabetes Association and the European Association for the Study of Diabetes. Diabetes Care. 2009;32:193-203.

13. Tibaldi J. Importance of postprandial glucose levels as a target for glycemic control in type 2 diabetes. South Med J. 2009;102: 60-66.

14. Chau D. Clinical management of diabetes in the elderly. Clin Diabetes. 2001;19:172-175.

15. Abbatecola AM, Maggi S, Paolisso G. New approaches to treating type 2 diabetes mellitus in the elderly: role of incretin therapies. Drugs Aging. 2008;25:913-925.

16. White J. Efficacy and safety of incretin based therapies: clinical trial data. J Am Pharm Assoc (2003). 2009;49(Suppl 1):S30-S40.

17. Spollett G. Insulin devices: addressing barriers to insulin therapy with the ideal pen. Diabetes Educ. 2008;34:957-967.

18. Li Y, Xu W, Liao Z, et al. Induction of long-term glycemic control in newly diagnosed type 2 diabetic patients is associated with improvement of beta-cell function. Diabetes Care. 2004;27:2597-2602.

19. Bolen S, Wilson L, Vassy J, et al. Comparative effectiveness and safety of oral diabetes medications for adults with type 2 diabetes. Comparative effectiveness review. Rockville, MD: Agency for Healthcare Research and Quality; 2007

20. Blonde L, Brixner D, Jacobs M. The rationale for early, aggressive treatment of type 2 diabetes: the cost ramifications of improved health outcomes. Managed Care. 2004;13(Suppl):S4-S21.

21. Lee WC, Balu S, Cobden D, Joshi AV, Pashos CL. Medication adherence and the associated health-economic impact among patients with type 2 diabetes mellitus converting to insulin pen therapy: an analysis of thirdparty managed care claims data. Clin Ther. 2006;28:1712-1725.

22. Bray B. Transitioning and adjusting insulin analog therapy in elderly patients. Consultant Pharm. 2008;23(Suppl B):17-23. 
23. Wubben DP, Vivian EM. Effects of pharmacist outpatient interventions on adults with diabetes mellitus: a systematic review. Pharmacotherapy. 2008;28:421-436.

24. Cranor CW, Bunting BA, Christensen DB. The Asheville Project: longterm clinical and economic outcomes of a community pharmacy diabetes care program. J Am Pharm Assoc (Wash). 2003;43:173-184.
25. Jameson JP, Baty PJ. Pharmacist collaborative management of poorly controlled diabetes mellitus: a randomized controlled trial. Am J Manag Care. 2010;16:250-255.

\section{Publish your work in this journal}

The Journal of Multidisciplinary Healthcare is an international, peerreviewed open-access journal that aims to represent and publish research in healthcare areas delivered by practitioners of different disciplines. This includes studies and reviews conducted by multidisciplinary teams as well as research which evaluates the results or conduct of such teams or healthcare processes in general. The journal covers a wide range of areas and welcomes submission from practitioners at all levels, from all over the world. The manuscript management system is completely online and includes a very quick and fair peer-review system. Visit http://www.dovepress.com/testimonials.php to read real quotes from published authors.

Submit your manuscript here: http://www.dovepress.com/journal-of-multidisciplinary-healthcare-journal 